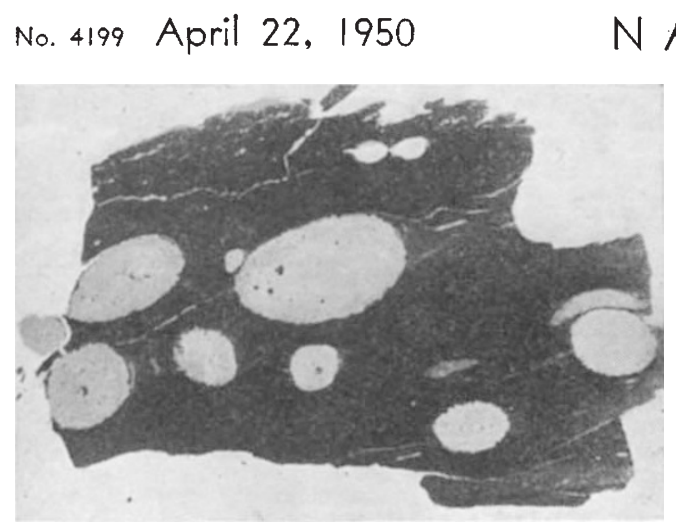

Thin section of oil-shale from near Ratta (Salt Range) showing
resins. $\times 3$

Cambrian) coal found interbedded with the Vindhyan limestones is algal in nature, and does not show any evidence of being derived from vascular plants as is the case in the Punjab oil-shales.

Bituminous oil-shales are found interbedded with the upper and lower gypsum-dolomite stages of the Saline series in several localities, and microscopic examination of numerous thin sections has shown that resins are invariably present though in minute quantities. Oil-shales from near Ratta, in the Chittidil area, however, show a rich concentration of resin bodies often exceeding $1 \mathrm{~cm}$. in length. The Ratta samples come from a section which Dr. Gee has regarded as critical evidence for his overlap theory, and the sequence as noted by him is as follows :

Talchir boulder-bed -undisturbed sedimentary contact-

Upper Gypsum - Dolomite stage of the Saline series with bands of cherts and cherty dolomites alternating with kengent.

A thin section of the oil-shale mentioned in the above sequence is shown in the accompanying photograph. The ovoid resin bodies are transparent, pale golden-yellow in colour and lie with their long axes nearly parallel to one another and to the lamination of the shale. The resins contain some brown, highly decomposed plant tissues and also microscopic crystals of pyrites and air-bubbles. No recognizable organic remains were found. It is difficult to conceive that the resins are derived from any source other than the vegetation which has given rise to the oil-shales.

No pre-Carboniferous fossil resins seem to have been hitherto recognized. David White proved that resins are present in Carboniferous coals of a somewhat low bituminous rank. According to Sir Cyril Fox ${ }^{5}$, Indian Gondwana (Middle to Upper Permian) and Jurassic coals contain no resin ; I have, however, noticed resins in a carbonaceous shale from the Middle Productus limestones (Late Permian) of the Nammal gorge (in the western part of the Salt Range). Thiessen ${ }^{6}$ makes the observation that all coals from Carboniferous to Cretaceous have been derived largely from conifers which were probably the chief source of resins in coals of these ages. A few occurrences of coal of Devonian age are known but they are non-resinous; nor do we find any mention of secretory cells or strands in well-preserved Devonian plants.

Since Dr. Gee has suggested a Vindhyan age for the Saline series, a brief reference may be made to the coal which occurs as lenticles in the Vindhyan limestones. Thin sections of this coal (which is being investigated by my colleague Dr. R. C. Misra?) do not show any evidence of vascular plants; that it probably owed its origin to marine algæe is demon- strated by the discovery of a primitive Dasycladacea allied to the Ordovician genus Coelosphceridium in it. Further evidence of its algal origin is furnished by dusky patches of calcium carbonate similar to the 'algal dust' which Dr. Alan Wood's has described from the Lower Carboniferous limestones of England. It is obvious that the Vindhyan coal and the Punjab oil-shales are derived from totally different types of vegetation, and there is no evidence to suggest that the two are contemporaneous.

Geology Department,

S. R. Narayana RaO

University of Lucknow. Dec. 3.

${ }^{1}$ Gee, E. R., Abstr. Proc. Geol. Soc., London, No. 1453 (1949).

${ }^{3}$ Sahni, B., Proc. Nat. Acad. Sci., Allahabad, 16 (1946). 3 Ghosh and Bose, Nature, 160, 796 (1947). Ghosh, Sen and Bose,
Proc. Ind. Sci. Congr. (1948).

- White, D., U.S. Geol. Surv., Prof. Paper No. 85 (1914).

'Fox, C. S., Mem. Geol. Surv. Ind., 57, 73 (1931).

"Cited by Moore, E. S., "Coal", 173 (1947).

${ }^{7}$ Misra, R. C., Curr. Sci., 18, No, 12 (1949).

Wood, A., Geol. Mag., r8, 192 (1941).

\section{An Unusual Rh Chromosome Combination}

What must be an extremely rare $R h$ chromosome, $C w D u_{e}$, has been recognized in a person whose genotype is $C w D u_{e} / c d e$.

The $C^{t o}$ gene, which is allelomorphic to $C$ and $c$, has a frequency in English people of 1.29 per cent $t^{2}$; it has been identified in the combination $C w D e$ and $C^{v} d^{2}$. The equivalent antigen is demonstrated by the use of a pure anti. Cw serum, of which several examples have now been found.

The gene $D u$, an allelomorph of $D$ and $d^{s}$, occurs in the combinations $C D^{u} e, c D u E$ and $c D^{u} e$, with a frequency not yet precisely determined but which probably does not exceed 1 per cent of English blood samples. No pure anti- $D u_{\text {-serum has yet been found. } D u d \text { red }}$ cells are recognized by their giving some, but not all, of the reactions expected of $D$; the reason for this is that some sera are anti- $D$ in specificity, others anti- $D+D^{u}$. There appear to be many slight, but heritable, variations of $D u$.

The proposita and two of her cousins are of the genotype $C w D^{u} e / c d e$; and, in conformity with previous experience ${ }^{4}$, the grade of $D^{u}$ is the same in all three members of the family. The mother of the proposita is of the genotype CwDue/CDe, and the maternal aunt $C^{w} D^{u} / c D E$ : the presence of $D u$ in these two people has to be assumed from the pedigree evidence, for the antigen is masked, serologically, by the accompanying $D$.

That $C w D u_{e}$ should exist follows as a consequence of Fisher's demonstration of the three series of allelomorphic antigens; its identification in this family provides yet further-though now almost superfluous-evidence for the correctness of Fisher's views.

The readiness of the family to co-operate in the investigation is very much appreciated.

Red Cross Blood Transfusion Service, Ruth SANGer Sydney, New South Wales. Dec. 12.

${ }^{2}$ Race, R. R., Mourant, A. E., Lawler, Sylvia D., and Sanger, Ruth, Blood: the Journal of Hematology, 3, 689 (1948)

${ }^{2}$ Callender, Sheils and Race, R. R., Ann. Eugen., 13, 102 (1946).

Stratton, F., Nature, 158, 25 (1946).

'Race, R. R., Sanger, Ruth, and Lawler, Sylvia D., Nature, 162, 292 